\title{
ANALISIS PENGARUH CELEBRITY ENDORSE RIZKY FEBIAN TERHADAP MINAT PEMBELIAN PRODUK TEH KOTAK RASA BUAH (STUDI KASUS PADA MASYARAKAT KABUPATEN BANTUL)
}

\author{
Danti Shela Intan \\ Sri Hardjanti \\ Universitas Islam Indonesia \\ sri_hardjanti@uii.ac.id
}

\begin{abstract}
Celebrity endorser has become one popular approach for marketing communication. This study aims to determine the effect of using celebrity endorser on customer's buying intentions. This study focus on variables on celebrity endorser which are trust, honesty, and attractiveness and their effect on customer's buying intentions. Object of this study are customers of fruit flavored tea product. Data collection technique is questionnaire that are distributed to customers at productive age in Bantul Regency Yogyakarta. By using SPSS to analyze the data, this study found that Celebrity Endorser's variables which are trust, honesty, and attractiveness have a positife effect on customer's buying interest.
\end{abstract}

Keywords: Celebrity Endorse; Trust; Honesty; Attractiveness; Interest In Buying.

\section{PENDAHULUAN}

Perkembangan dunia bisnis pada saat ini sangatlah pesat, persaingan semakin ketat, namun peluang bisnis juga semakin luas. Salah satu permasalahan dalam bisnis adalah perihal pemasaran. Pemasaran pada saat ini menuntut suatu perusahaan harus bisa mengkomunikasikan dan menyampaikan dengan baik produknya kepada konsumen. Definisi pemasaran menurut Kotler (2007) adalah suatu fungsi organisasi dan seperangkat proses untuk menciptakan, mengkomunikasikan, dan menyerahkan nilai kepada pelanggan dan mengelola hubungan pelanggan dengan cara yang menguntungkan organisasi dan para pemegang saham.

Dalam pemasaran suatu produk, terdapat kegiatan yang pastilah bertujuan untuk mempengaruhi konsumen, agar mereka tertarik pada produk yang ditawarkan dan kemudian membeli produk tersebut. Pemasaran membawa pengaruh besar pada penjualan dan profitabilitas perusahaan. Ketika perusahaan dapat memasarkan produk dengan baik dan produk tersebut bisa sampai ke konsumen, maka produk itu akan banyak peminatnya, apalagi dapat menciptakan citra yang baik di benak konsumen, otomatis penjualan dan profitabilitas perusahaan meningkat yang pada akhirnya konsumen akan loyal terhadap produk perusahaan. Perusahaan akan mengeluarkan biaya yang cukup besar ketika pertama kali mengeluarkan produk baru. Biaya yang dikeluarkan tersebut untuk biaya pemasaran, namun biaya tersebut akan kembali dan menghasilkan profitabilitas ketika kegiatan iklan atau promosi tersebut sukses menarik minat beli konsumen.

Untuk mendukung proses pemasaran tersebut suatu perusahaan perlu melakukan promosi penjualan. Promosi penjualan adalah insentif yang dirancang untuk mendorong 
pembelian atau penjualan sebuah produk biasanya untuk jangka pendek (Kotler, 2004). Promosi penjualan salah satu kegiatan yang penting dalam pemasaran suatu produk yang dilakukan oleh sebagian besar organisasi termasuk produsen, pengecer, organisasi lainnya, dan promosi penjualan merupakan unsur kunci dalam kampanye pemasaran (Darmadi, 2013). Pengertian lain menjelaskan promosi penjualan merupakan kegiatan komunikasi pemasaran, selain periklanan, penjualan pribadi, dan hubungan masyarakat, dimana insentif jangka pendek akan memotivasi konsumen dan semua saluran distribusi untuk membeli barang atau jasa dengan cepat. Kemudian dapat disimpukan bahwa promosi penjualan merupakan salah satu bentuk komunikasi pemasaran yang menawarkan nilai lebih untuk suatu produk (Natalia, 2014).

Tujuan dari promosi penjualan adalah untuk meningkatkan penjualan jangka pendek atau membantu menciptakan pangsa pasar untuk jangka panjang, promosi penjualan harus menciptakan hubungan dengan konsumen, bukan hanya memikirkan hubungan jangka pendeknya saja tetapi juga hubungan jangka panjang kedepannya akan bagaimana dengan konsumen (Kotler, 2004). Kegiatan promosi sangat beraneka ragam, salah satunya iklan. Iklan sebagai bentuk dari komunikasi yang bukan pribadi, perusahaan membayar perusahaan yang membuat iklan. Iklan juga merupakan bentuk popular dari promosi (Lamb, 2001) Di era digital seperti sekarang banyak perusahaan yang menggunakan strategi iklan untuk mempromosikan dan memasarkan produknya. Iklan merupakan bagian dari kegiatan pemasaran yang bertujuan untuk memberikan informasi kepada konsumen tentang suatu produk, baik itu dari segi manfaat, kelebihan, keunikan suatu produk. Media iklan juga sangat beraneka ragam seperti media cetak, elektronik, internet, dan masih banyak lagi. Terlebih di zaman yang serba digital seperti sekarang ini, perusahaan dapat memanfaatkan media sosial untuk mengiklankan produk. Perusahaan juga bisa menggandeng selebritis atau tokoh publik dalam mengiklankan produknya.

Banyak perusahaan yang saat ini menghabiskan sejumlah anggarannya untuk menggunakan selebriti untuk mendukung iklan produk mereka. Perusahaan-perusahaan mempunyai tujuan untuk mendapatkan pengembalian investasi yang memadai dengan harapan bahwa para endorser ini menangkap perhatian calon pelanggan mereka, memperkuat ingatan merek, meningkatkan daya tarik produk, dan memiliki kontribusi yang signifikan terhadap niat pembelian konsumen. Banyak produk yang menggandeng selebritis untuk dijadikan endorser dan pelanggan akan dihadapkan dengan banyak pilihan. Banyak perusahaan mengiklankan produk mereka secara agresif sehingga akan diingat dan disukai di atas yang lain. Meskipun ada berbagai pendekatan untuk iklan, penggunaan endorser untuk meningkatkan persuasi iklan.

Salah satu produk yang menggunakan celebrity endorser adalah produk teh kotak perusahaan PT. Ultrajaya Milk Industry, Tbk. Dengan keluarnya teh kotak rasa buah mereka mengiklankan produk baru dengan menggandeng artis sekaligus penyanyi pendatang baru yang mempunyai suara bagus dan sedang digemari remaja pada umumnya yaitu Rizky Febian. Rizky Febian adalah anak dari salah satu komedian terkenal Sule yang mempunyai suara bagus dan lagu-lagunya yang sedang booming.

Kemampuan celebrity endorser dalam mengiklankan suatu produk sangat berpengaruh karena konsumen akan tertarik pada selebritis yang mengiklankan suatu produk dan juga menguasai produk tersebut, sehingga bisa meyakinkan kepada konsumen bahwa produk ini bagus dan sangat patut untuk dibeli. Kemampuan yang harus dimiliki celebrity endorser di antaranya trustworthiness (kepercayaan), expertise (keahlian yang mengacu pada pengetahuan), dan attractiveness (daya tarik fisik). Trustworthiness (kepercayaan) mengacu pada kejujuran, integritas, dan dapat dipercayainya seorang sumber, expertise (keahlian) mengacu pada pengetahuan, pengalaman, dan keahlian yang dimiliki oleh seorang endorser, 
attractiveness (daya tarik fisik) mengacu pada diri yang dianggap sebagai hal yang menarik untuk dilihat (Cholifah, 2016).

\section{REVIEW LITERATUR DAN HIPOTESIS}

\section{Landasan Teori}

\section{Minat Beli Konsumen}

Proses pembelian terjadi ketika konsumen sudah mulai mengenali masalah atau kebutuhan. Kebutuhan tersebut dapat ditimbulkan oleh kondisi eksternal maupun internal, seperti ketika lapar atau haus maka membutuhkan makan dan minum. Para pelaku bisnis perlu melakukan identifikasi keadaan yang memicu kondisi tersebut dengan mengumpulkan informasi dari beberapa konsumen. Untuk selanjutnya pelaku bisnis dapat memotivasi konsumen dan menyusun strategi pemasaran yang memicu minat beli konsumen (Kotler, 2007).

Minat beli merupakan bagian dari komponen perilaku sikap konsumtif. Menurut Dama (2016) minat beli adalah bagian dari komponen perilaku konsumen dalam sikap mengkonsumsi sesuatu, serta kecenderungan responden untuk bertindak sebelum keputusan membeli benar-benar dilaksanakan. Sedangkan minat beli ulang merupakan minat pembelian yang didasarkan atas pengalaman pembelian yang telah dilakukan di masa lalu. Ada perbedaan antara pembelian aktuial dengan minat beli. Apabila pembelian actual adalah pembelian yang benatbenar dilakukan oleh konsumen, maka minat beli adalah niat untuk melakukan pembelian di masa yang akan datang.

Minat pembelian (purchase intention) merupakan salah satu tahap dalam proses pembelian oleh konsumen. Pada tahap tertentu konsumen telah melakukan pencarian dan mengevaluasi informasi dari alternatif-alternatif merek, sehingga membuat keputusan pembelian. Sebagai hasil dari tahap pengevaluasian alternatif tersebut, konsumen mengembangkan sebuah niatan pembelian (purchase intention) atau kecenderungan untuk membeli (Hafisa, 2018).

Minat beli merupakan pernyataan mental dari konsumen yang merefleksikan rencana pembelian sejumlah produk dengan merek tertentu. Maka dari itu, sangat diperlukan oleh para pemasar untuk mengetahui minat beli konsumen terhadap suatu produk, baik para pemasar maupun ahli ekonomi menggunakan variabel minat untuk memprediksi perilaku konsumen di masa yang akan datang (Hafisa, 2018).

Konsumen yang terangsang kebutuhannya akan termotivasi untuk mencari informasi yang lebih banyak tentang produk perusahaan. Terdapat dua level rangsangan, pertama situasi pencarian informasi yang lebih ringan atau penguatan perhatian. Pada level ini orang mungkin hanya sedikit lebih peka terhadap suatu produk. Kedua, orang mulai aktif mencari informasi untuk mempelajari produk tertentu seperti mencari bahan bacaan, mengunjungi toko, menghubungi teman, mencari informasi di internet, dan sebagainya (Kotler, 2007). Sumber informasi konsumen digolongkan ke dalam empat kelompok (Kotler, 2007):

a. Sumber pribadi: keluarga, teman, tetangga, kenalan.

b. Sumber komersil: iklan, wiraniaga, penyalur, kemasan, pajangan toko.

c. Sumber publik: media massa, organisasi penentu peringkat konsumen.

d. Sumber pengalaman: penanganan, pengkajian, dan pemakaian produk.

Rata-rata konsumen mendapatkan informasi tentang produk melalui sumber komersil. Akan tetapi, informasi yang lebih efektif biasanya dari sumber pribadi atau sumber publik. Konsumen mempercayai sumber pribadi karena mereka mempercayai orang-orang terdekat mereka, sedangkan sumber publik karena 
mereka lebih banyak menghabiskan waktu dengan teknologi seperti handphone, televisi, dan komputer. Di era modern ini konsumen akan lebih banyak mendapatkan informasi di internet, jadi mereka lebih banyak mendapatkan informasi dari sumber publik (Kotler, 2007).

Dari pengumpulan informasi tersebut kemudian konsumen dapat mengetahui perbedaan antar merek, dari berbagai merek mungkin hanya beberapa yang masuk ke dalam pilihan merek calon pembeli. Pembeli akan melakukan berbagai evaluasi sebelum menentukan produk yang akan dibeli. Evaluasi sering mencerminkan keyakinan dan sikap. Keyakinan adalah gambaran pemikiran yang dianut seseorang tentang gambaran sesuatu yang pada akhirnya mempengaruhi keputusan pembelian merek. Sikap adalah evaluasi, perasaan emosi, dan kecenderungan tindakan yang menguntungkan atau tidak menguntungkan dan bertahan lama pada seseorang terhadap obyek atau gagasan tertentu. Sebaiknya perusahaan menyesuaikan produknya dengan sikap orang, bukan mengubah sikap orangnya (Kotler, 2007).

\section{Daya Tarik Iklan}

Periklanan (advertising) adalah suatu proses komunikasi massa yang melibatkan sponsor tertentu yaitu pemasang iklan (pengiklan), yang membayar jasa sebuah media massa atas penyiaran iklannya (Ardiansyah, 2015). Tujuan pemasangan iklan dapat dikelompokkan berdasarkan tujuan utamanya yaitu:

a. Menginformasikan. Pemasangan iklan informatif digunakan khususnya ketika memperkenalkan kategori produk baru.

b. Membujuk. Pemasangan iklan persuasif menjadi lebih penting ketika persaingan meningkat. Di sini tujuan perusahaan adalah menciptakan permintaan selektif. c. Mengingatkan. Pemasangan iklan yang mengingatkan penting bagi produk yang sudah dewasa, iklan tersebut akan membuat konsumen terus-menerus memikirkan produk tersebut.

Fungsi iklan dalam pemasaran adalah memperkuat dorongan kebutuhan dan keinginan konsumen terhadap suatu produk untuk mencapai pemenuhan kepuasannya agar iklan berhasil menarik konsumen (Ardiansyah, 2015). Adapun pengertian daya tarik iklan secara komprehensif menurut Kotler (dalam Hafisa, 2018) adalah segala bentuk penyajian dan promosi ide, barang atau jasa secara non-personal oleh suatu sponsor tertentu yang memerlukan pembayaran. Daya tarik iklan atau power of impression dari suatu iklan adalah seberapa besar iklan mampu memukau atau menarik perhatian pemirsanya. Daya tarik iklan (advertising appeal) mengacu pada pendekatan yang digunakan untuk menarik perhatian konsumen dan mempengaruhi perasaan mereka terhadap suatu produk.

Menurut Morissan (dalam Hafisa, 2018) iklan yang menarik adalah iklan yang mempunyai daya tarik, yaitu memiliki kemampuan untuk menarik pasar (audience) sasaran. Pesan-pesan yang akan disampaikan dapat disajikan dalam gaya penyampaian yang berbeda-beda, yaitu dengan menampilkan cuplikan kehidupan individu atau kelompok, gaya hidup individu, fantasi tentang produk, suasana hati (mood) atau seputar citra produk, musik untuk lebih menghidupkan pesan, simbol kehidupan untuk menciptakan karakter yang mempersonifikasikan produk, memamerkan keahlian dan pengalaman perusahaan dalam menghasilkan produk, bukti ilmiah keunggulan produk, bukti kesaksian dari orang-orang terkenal (Hafisa, 2018).

Russel (dalam Ardiansyah, 2015) menyatakan adanya unsur-unsur yang diperlukan iklan televisi agar memiliki daya tarik yang kuat, yaitu: 
a. Music atau Jingle adalah musik yang terdapat dalam iklan, bisa berupa lagu atau hanya musik ilustrasi sebagai background.

b. Storyboard adalah visualisasi untuk iklan televisi yang merupakan rangkaian gambar yang menampilkan alur cerita.

c. Copy atau Script adalah susunan suatu kalimat yang membentuk headline atau pesan utama dalam sebuah iklan.

d. Endorser adalah pengguna tokoh pendukung yang dapat digunakan sebagai pemeran iklan yang bertujuan untuk memperkuat pesan yang disampaikan.

e. Signature Slogan atau Strapline (barisan penutup), dapat ditampilkan dalam bentuk suara (voice) saja, visual (tulisan/gambar) saja atau audio dan visual (tulisan/gambar dan suara).

f. Logo, digunakan agar khalayak dengan mudah mengetahui dan mengenali produk/perusahaan atau siapa yang menampilkan iklan tersebut.

\section{Sikap terhadap Iklan}

Sikap terhadap iklan didefinisikan sebagai kecenderungan untuk merespon dengan cara yang menguntungkan atau tidak menguntungkan terhadap stimulus iklan tertentu selama acara paparan tertentu. Istilah ini sebagai upaya untuk mempengaruhi pilihan konsumen melalui penciptaan sikap yang menguntungkan yang dapat mengalihkan ke merek yang diiklankan dan mempengaruhi perilaku pilihan (Rodriguez, 2008).

Imasari (2010) mengemukakan bahwa daya tarik iklan (attention) harus mempunyai tiga sifat: pertama, iklan harus bermakna (meaningful), menunjukkan manfaat-manfaat yang membuat produk lebih diinginkan atau lebih menarik bagi konsumen. Kedua, pesan iklan harus dapat dipercaya (believable), konsumen percaya bahwa produk tersebut akan memberikan manfaat seperti yang dijanjikan dalam pesan iklan. Ketiga, distinctive, bahwa pesan iklan lebih baik dibanding iklan merek pesaing.

\section{Celebrity Endorser}

Seorang endorser adalah orang yang membuat testimoni atau pernyataan tertulis atau lisan, memuji kebaikan suatu produk. Orang ini bisa menjadi tokoh publik atau masyarakat umum. Kesaksian biasanya berlaku untuk penawaran penjualan yang dikaitkan dengan masyarakat umum sedangkan dukungan biasanya berlaku untuk promosi oleh selebritas (Rodriguez, 2008).

Celebrity endorser sebagai siapa pun yang menikmati pengakuan publik dan yang menggunakan pengakuan atas nama konsumen dengan tampil bersama dalam iklan (Rodriguez, 2008). Definisi lain menjelaskan selebriti sebagai individu yang dikenal publik (seperti aktor, tokoh olahraga, penghibur). Konsep dari celebrity endorsement banyak digunakan oleh para pelaku pemasaran karena memiliki dampak untuk mempengaruhi, yaitu pesan tentang sebuah merek atau produk (Rodriguez, 2008).

Celebrity endorser adalah celebrity yang meminjamkan namanya dan tampil untuk mewakili sebuah produk atau jasa suatu perusahaan. Mereka dapat menarik perhatian atas pesan iklan di tengah banyaknya iklan lain. Selebriti dapat digunakan sebagai alat yang cepat untuk mewakili segmen pasar yang dibidik dan disadari atau tidak, pesan yang disampaikan oleh sumber yang menarik (kaum selebriti yang sedang naik daun) akan mendapat perhatian yang lebih besar disamping sangat mudah diingat (Sintani, 2016).

Program selebriti yang telah direncanakan dengan cara yang sukses dapat mengubah persepsi negatif pada produk dan layanan yang diiklankan. Pilihan selebriti yang tepat dapat efektif 
dalam menetapkan posisi untuk produk yang baru diluncurkan dan juga dapat mengubah persepsi pada produk yang telah diposisikan dengan cara yang salah.

Menurut Sintani (2016) terdapat lima karakteristik celebrity endorser yang disebut dengan model TEARS, meliputi:

a. Trustworthiness, mengacu pada kemampuan untuk dipercaya, kejujuran, serta integritas dari celebrity.

b. Expertise, mengacu pada pengetahuan, pengalaman, atau keterampilan yang dimilki oleh seorang endorser.

c. Attractiveness, mengacu pada sejumlah karakteristik fisik yang dapat dilihat orang dalam diricelebrity tersebut, misalnya ketampanan atau kecantikan, keatletisan tubuh, dan lain sebagainya.

d. Respect, mengacu pada endorser yang dikagumi dan dihormati oleh konsumen karena kualitas pribadi dan prestasinya.

e. Similarity, merupakan atribut yang penting karena lebih mudah bagi konsumen untuk berhubungan dengan endorser yang memiliki karakteristik yang sama dengan diri konsumen tersebut.

\section{Source Credibility}

Endorser adalah orang yang membuat testimoni atau pernyataan tertulis atau lisan, memuji kebaikan suatu produk. Orang ini bisa menjadi tokoh publik atau masyarakat umum. Kesaksian biasanya berlaku untuk penawaran penjualan yang dikaitkan dengan masyarakat umum sedangkan dukungan biasanya berlaku untuk promosi oleh selebritas (Rodriguez, 2008).

Sumber kredibilitas pesan sebagai sebuah istilah yang biasa digunakan untuk menyiratkan karakteristik positif seorang komunikator yang mempengaruhi penerimaan penerima pesan. Istilah ini memiliki tiga dimensi, yaitu daya tarik, kepercayaan, dan keahlian. Mengacu pada kredibilitas endorser sebagai sejauh mana sumber dianggap memiliki keahlian yang relevan dengan topik komunikasi dan dapat dipercaya untuk memberikan opini obyektif tentang subjek kedua variabel di atas. Jenis endorser dan kredibilitas sumber pesan dikatakan mempengaruhi tiga faktor yang pada akhirnya mempengaruhi efektivitas iklan. Tiga faktor tersebut adalah sikap terhadap iklan, sikap terhadap merek, dan niat membeli (Rodriguez, 2008).

Sumber kredibilitas menyatakan bahwa keefektifan suatu pesan bergantung pada tingkat keahlian yang dirasakan dan kepercayaan dari seorang pendukung. Informasi dari sumber yang dapat dipercaya akan mempengaruhi keyakinan, pendapat, sikap dan atau perilaku melalui proses yang disebut internalisasi, yang terjadi ketika penerima merangkul pengaruh sumber dalam hal sikap pribadi mereka dan struktur nilai. Sertoglu (2014) menyebutkan bahwa kredibilitas sumber biasanya digunakan untuk memperhatikan karakteristik positif komunikator yang mempengaruhi penerimaan penerima pesan. Karena Celebrity endorser adalah sumber informasi utama dan kredibilitasnya merupakan pertimbangan penting bagi pengiklan.

Kredibilitas terdiri dari dua komponen yang disebut keahlian yang dirasakan dan kepercayaan. Kepercayaan adalah komponen penting dalam banyak penelitian dan sisi negatif dari kepercayaan sebagai komponen utama kredibilitas karena pembicara yang tidak dapat dipercaya. Terlepas dari kualitasnya yang lain, kepercayaan dipandang sebagai sumber pesan yang dipertanyakan. Selain kepercayaan, keahlian (dan atau kompetensi) juga disebutkan sebagai faktor penting dari sumber kredibilitas. Daya tarik sumber juga diterima sebagai dimensi kredibilitas. Skala untuk mengukur efektivitas celebrity endorser melalui melihat keahlian, kepercayaan 
dan daya tarik dari endorser, terutama dalam proses iklan (Sertoglu, 2014).

\section{Hipotesis}

1. Pengaruh Positif Trustworthiness terhadap Minat Beli

Paradigma kepercayaan dalam komunikasi adalah tingkat kepercayaan pendengar dan tingkat penerimaan, pembicara dan pesan. Komunikator dapat dipercaya adalah persuasif, apakah seorang ahli atau tidak. Kepercayaan dapat didefinisikan sebagai kejujuran, integritas dan kepercayaan yang dimiliki oleh endorser. Ini adalah tingkat kepercayaan konsumen dalam niat komunikator untuk menyampaikan pernyataan yang dianggapnya paling valid.

Efektif atau tidaknya suatu iklan tergantung juga pada kepercayaan konsumen terhadap celebrity endorser, sebab ketika konsumen mempercayai seorang selebriti, maka ketika adanya iklan yang dibintangi oleh selebriti tersebut konsumen bisa tertarik dengan produk itu atau bisa menimbulkan minat beli. Dalam penelitian Sertoglu (2014) banyak literatur mendukung efek positif dari kepercayaan pada efektivitas. Dari penelitian Lolasary (2015) variabel trustworthiness atau kepercayaan berpengaruh positif terhadap minat beli konsumen. Berdasarkan uraian di atas, maka dapat dirumuskan hipotesis sebagai berikut:

\section{H1 :Terdapat Pengaruh Positif Trustworthiness terhadap Minat Beli}

\section{Pengaruh Positif Expertise terhadap Minat Beli}

Expertise juga disebut sebagai otoritativeness, kompetensi, expertness, atau kualifikasi. Keahlian adalah sejauh mana endorser dianggap memiliki pengetahuan, pengalaman, atau keterampilan yang memadai untuk mempromosikan produk. Keahlian dari endorser tidak penting kecuali konsumen menganggapnya demikian. Keahlian diterima sebagai komponen yang paling penting untuk disetujui agar berhasil. Selebriti mungkin dianggap memiliki keahlian lebih dari juru bicara yang dibuat. Keahlian celebrity endorser adalah sejauh mana komunikator dianggap sebagai sumber pernyataan yang sah (Sertoglu, 2014).

Hubungan antar expertise keahlian celebrity endorser dengan minat beli sangatlah erat. Ketika seorang celebrity endorser itu memiliki keahlian, maka itu menjadi daya tarik tersendiri bagi konsumen. Dibandingkan dengan juru bicara, iklan yang dibintangi oleh celebrity endorser yang memiliki keahlian lebih menarik dan dapat menimbulkan minat beli dibandingkan dengan iklan yang tidak menampilkan suatu keahlian atau biasa saja. Dari penelitian Lolasary (2015) variabel expertise berpengaruh positif terhadap minat beli konsumen. Berdasarkan uraian di atas, maka dapat dirumuskan hipotesis sebegai berikut:

\section{H2 :Terdapat Pengaruh Positif} Expertise terhadap Minat Beli.

\section{Pengaruh Positif Attractiveness terhadap Minat Beli}

Attractiveness adalah komponen penting dari kredibilitas, daya tarik adalah stereotip dari asosiasi positif kepada seseorang dan tidak hanya memiliki daya tarik fisik tetapi juga karakteristik lain seperti kepribadian dan kemampuan atletik. Bukti eksperimental mengenai dampak komunikator yang menarik secara fisik pada berbagai tindakan tergantung, dan menyatakan bahwa komunikator yang menarik lebih disukai, disukai, dan diyakini memiliki dampak positif pada produk daripada yang tidak menarik. Endorser yang dianggap menarik lebih cenderung mengarahkan niat pembelian.

Attractiveness atau daya tarik dapat menjadi faktor penting dalam menciptakan pesan yang efektif. Menarik endorser memiliki lebih banyak pengaruh atas konsumen dibandingkan dengan 
yang kurang menarik. Dalam penelitian Sertoglu (2014) daya tarik secara positif mempengaruhi evaluasi, itu tidak material dalam mempengaruhi niat pembelian. Meskipun pengiklan sering memilih pendukung berdasarkan daya tarik fisik mereka untuk mempengaruhi sikap konsumen. Dalam penelitian ini juga menyatakan bahwa sumber daya tarik mungkin hanya efektif jika produk meningkatkan daya tarik pengguna sebagaimana juga dinyatakan dalam model pencocokan. Penelitian Prabowo (2014) variabel attractiveness berpengaruh positif terhadap minat beli konsumen. Dari penelitian Lolasary (2015) variabel Attractiveness berpengaruh positif terhadap minat beli konsumen. Berdasarkan uraian di atas, maka dapat dirumuskan hipotesis sebagai berikut:

H3 :Terdapat Pengaruh Positif Attractiveness terhadap Minat Beli.

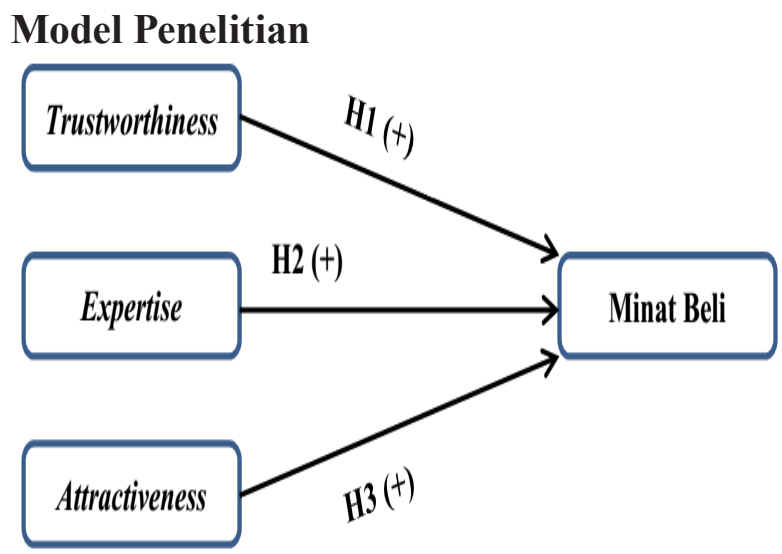

Gambar 2.1. Model Penelitian

\section{METODE PENELITIAN}

\section{Populasi dan Sampel}

Subjek penelitian ini adalah masyarakat di Kabupaten Bantul Daerah Istimewa Yogyakarta yang melihat iklan teh kotak di televisi maupun media sosial lainnya, dan tertarik membeli karena celebrity endorsernya maupun yang tidak tertarik, baik yang sudah pernah mencoba produk baru teh kotak maupun yang belum.

Menurut data yang ada pada tahun penelitian, jumlah penduduk Kabupaten Bantul yang berjenis kelamin laki-laki dan perempuan usia 15-54 tahun berjumlah 646.937. Perhitungan sampel untuk penelitian ini adalah:

$$
n=\frac{N}{1+N(m o e)^{2}}
$$

Keterangan:

$\mathrm{n} \quad=$ jumlah sampel

$\mathrm{N}=$ jumlah populasi

Moe $=$ margin of error maximum, yaitu tingkat kesalahan maksimum yang masih dapat ditoleransi (ditentukan oleh peneliti $10 \%)$.

$$
\begin{gathered}
n=\frac{646.937}{1+646.937(10 \%)^{2}} \\
n=\frac{646.937}{1+6469,37} \\
n=\frac{126612}{6470,37} \\
n=99,98 \\
n=100
\end{gathered}
$$

Dari data di atas jumlah sampel yang diteliti sebanyak 99,92 atau dibulatkan menjadi 100 sampel.

\section{Variabel Penelitian}

\section{Variabel Dependen}

Minat beli adalah keadaan mental yang menceminkan rencana konsumen untuk membeli beberapa produk tertentu dengan merek tertentu pada periode waktu tertentu. Minat beli dipengruhi oleh sikap audiens terhadap iklan, dimana perubahan sikap yang relevan adalah mengubah kepercayaan mereka. Minat beli akan menyebabkan konsumen meramalkan penggunaan produk mereka di masa yang akan datang dan menghubungkan iklan tersebut dengan perasaan serta kepercayaannya sendiri. 


\section{Variabel Independen}

a. Trustworthness atau Kepercayaan

Paradigma kepercayaan dalam komunikasi adalah tingkat kepercayaan pendengar dan tingkat penerimaan. Komunikator yang dapat dipercaya adalah persuasif, apakah seorang ahli atau tidak. Kepercayaan dapat didefinisikan sebagai kejujuran, integritas dan kepercayaan yang dimiliki oleh endorser. Ini adalah tingkat kepercayaan konsumen dalam niat komunikator untuk menyampaikan pernyataan yang dianggapnya paling valid. Dalam penelitian Sertoglu (2014) banyak literatur mendukung efek positif dari kepercayaan pada efektivitas.

\section{b. Expertise atau Keahlian}

Expertise juga disebut sebagai otoritativeness, kompetensi, expertness, atau kualifikasi. Keahlian adalah sejauhmanaendorser dianggap memiliki pengetahuan, pengalaman, atau keterampilan yang memadai untuk mempromosikan produk. Keahlian dari endorser tidak penting kecuali konsumen menganggapnya demikian. Keahlian diterima sebagai komponen yang paling penting untuk disetujui agar berhasil. Selebriti mungkin dianggap memiliki keahlian lebih dari juru bicara yang dibuat. Keahlian celebrity endorser adalah sejauh mana komunikator dianggap sebagai sumber pernyataan yang sah (Sertoglu, 2014).

\section{c. Attractive atau Daya Tarik}

Attractiveness adalah komponen penting dari kredibilitas. Daya tarik adalah stereotip atau penilaian kepada seseorang hanya berdasarkan persepsi terhadap kelompok dimana orang tersebut dapat dikategorikan. Stereotip ini bisa berupa prasangka positif ataupun negatif kepada seseorang dan tidak hanya memiliki daya tarik fisik tetapi juga karakteristik lain seperti kepribadian dan kemampuan atletik. Bukti bukti nyata mengenai dampak komunikator yang menarik secara fisik tergantung pada berbagai tindakan, dan menyatakan bahwa komunikator yang menarik lebih disukai, disukai, dan diyakini memiliki dampak positif pada produk daripada yang tidak menarik. Endorser yang dipandang lebih menarik dapat menarik minat pembelian konsumen.

\section{Teknik Analisis Data}

\section{Uji Instrumen}

\section{a. Uji Validitas}

Uji validitas digunakan untuk mengukur sah atau valid tidaknya suatu kuesioner. Suatu kuesioner dikatakan valid jika pertanyaan pada kuesioner mampu untuk mengungkapkan sesuatu yang akan diukur oleh kuesioner tersebut (Ghozali dalam Hafisa, 2018). Instrumen pengukur dapat dikatakan memiliki validitas yang tinggi apabila alat tersebut memberikan hasil ukur yang sesuai dengan maksud yang dilakukan pengukurannya tersebut. Untuk uji validitas maka digunakan rumus korelasi product moment yaitu menurut (Sugiyono, 2005). Teknik korelasinya memakai pearson correlation, dihitung dengan menggunakan bantuan komputer program SPSS.

\section{b. Uji Reliabilitas}

Uji reliabilitas adalah pengujian untuk mengukur suatu kuesioner yang merupakan indikator dari variabel atau konstruksi. Suatu kuesioner dikatakan reliabel dan handal jika jawaban seseorang terhadap pertanyaan adalah konsisten atau stabil dari waktu ke waktu (Ghozali dalam Hafisa, 2018).

Teknik yang digunakan untuk mengukur konsistensi internal dalam penelitian ini dengan teknik 
cronbach's alpha (Ghozali, 2005). Untuk menghitung validitas dan reliabilitas digunakan komputer dengan program SPSS.

\section{Analisis Deskriptif}

Penelitian deskriptif dalam penelitian ini dengan menggunakan kuesioner yang disebarkan secara online maupun offline yang kemudian dilakukan analisis data, bertujuan agar mudah dimengerti dan mendapat gambaran yang jelas. Metode analisa ini diterangkan dalam bentuk prosentase disertai tabel dalam penyajiannya.

\section{Uji Asumsi Klasik}

\section{a. Uji Normalitas}

Uji normalitas data bertujuan untuk menguji apakah dalam model regresi, variabel dependen, maupun variabel independen mempunyai distribusi normal atau tidak. Model regresi yang baik adalah yang memiliki distribusi normal atau mendekati normal (Ghozali dalam Hafisa, 2018).

Uji normalitas bertujuan untuk mengetahui apakah residual model regresi yang diteliti normal atau tidak. Metode yang digunakan untuk menguji normalitas adalah dengan menggunakan uji KolmogorovSmirnov $>0,05$, maka asumsi normalitas terpenuhi.

\section{b. Uji Heteroskedastisitas}

Uji heteroskedastisitas bertujuan menguji apakah dalam model regresi terjadi ketidaksamaan variance dari residual satu pengamatan ke pengamatan yang lain. Jika variance dari residual satu pengamatan ke pengamatan lain tetap, maka terjadi homokedastisitas dan jika berbeda terjadi heteroskedastisitas. Model regresi yang baik adalah yang homokedastisitas atau tidak terjadi heteroskedastisitas. Deteksi ada tidaknya masalah heteroskedastisitas di dalam suatu penelitian adalah dengan media grafik scatterplot, apabila grafik membentuk pola khusus maka model terdapat heteroskedastisitas. Tetapi, jika tidak ada pola yang jelas, serta titik-titik menyebar di atas dan di bawah angka 0 pada sumbu Y, maka tidak terjadi heteroskedastisitas (Ghozali dalam Hafisa, 2018).

\section{c. Uji Multikolinieritas}

Tujuan dari uji multikolinieritas adalah untuk menguji adanya korelasi antar variabel independen. Model regresi yang baik seharusnya tidak terjadi korelasi diantara variabel independen. Jika variabel-variabel independen saling berkorelasi, maka variabel-variabel initidak orthogonal. Variabel orthogonal adalah variabel independen sama dengan nol. Untuk mendeteksi ada atau tidaknya multikolinieritas di dalam model regresi adalah dengan cara melihat nilai variance inflation factor (VIF). Jika nilai VIF lebih kecil dari 10 , maka tidak terjadi multikolinieritas. Begitu pula sebaliknya apabila nilai VIF lebih besar dari 10, maka terjadi multikolinieritas (Ghozali dalam Hafisa, 2018).

\section{Analisis Regresi Linier Berganda}

Metode analisis data yang digunakan dalam model ini adalah metode analisis regresi berganda (multiple regresional analisis). Analisis regresi berganda bermanfaat untuk mencari pengaruh dua atau lebih variabel prediktor atau untuk mencari hubungan fungsional dua variabel prediktor atau lebih terhadap variabel kriteriumnya, atau untuk meramalkan dua variabel prediktor atau lebih terhadap variabel kriteriumnya (Kumalasari, 2018).

Persamaan regresi yang akan digunakan untuk mengetahui pengaruh trustworthiness, expertise, attractive terhadap minat beli konsumen sebagai 
berikut:

$$
\mathrm{Y}=\mathrm{a}+\mathrm{b} 1 \mathrm{X} 1+\mathrm{b} 2 \mathrm{X} 2+\mathrm{b3} \mathbf{X 3}
$$

Keterangan:

$$
\begin{aligned}
\mathrm{Y}= & \text { Minat beli } \\
\mathrm{a} & =\text { Konstanta } \\
b 1, b 2, b 3= & \text { koefisien regresi variabel } \\
& \text { bebas } \\
\mathrm{X} 1 \quad= & \text { Trustworthiness } \\
\mathrm{X} 2 \quad= & \text { Expertise } \\
\mathrm{X} 3 \quad= & \text { Attractive }
\end{aligned}
$$

\section{Uji Hipotesis}

\section{a. Uji Parsial (Uji T)}

Uji $\mathrm{T}$ juga dapat dilakukan dengan membandingkan nilai $\mathrm{t}_{\text {hitung }}$ dengan nilai $\mathrm{t}_{\text {tabel }}$ pada tingkat signifikansi 0.05 atau 5\%. Apabila $\mathrm{t}_{\text {hitung }}>\mathrm{t}_{\text {tabel }} \mathrm{t} \alpha(\mathrm{n}-\mathrm{k})$, maka H0 ditolak yang berarti $\mathrm{X}$ berpengaruh terhadap Y. $\alpha$ adalah tingkat signifikansi dan (n-k) derajat bebas, yaitu jumlah $n$ observasi dikurangi jumlah variabel independen dalam model (Ghozali, 2011 dalam Kumalasari, 2018).

\section{b. Uji Koefisien Determinan}

Koefisien determinasi $\left(R^{2}\right)$ mengukur seberapa jauh kemampuan model dalam menerangkan variasi variabel dependen. Nilai koefisien determinasi adalah antara nol dan satu. Nilai $\left(R^{2}\right)$ yang kecil berarti kemampuan variabel-variabel independen dalam menjelaskan variasi variabel dependen amat terbatas. Nilai yang mendekati satu berarti variabel-variabel independen memberikan hampir semua informasi yang dibutuhkan untuk memprediksi variasi variabel dependen (Ghozali, 2011 dalam Kumalasari, 2018).

Kelemahan mendasar penggunaan koefisien determinasi adalah bias terhadap jumlah variabel independen yang dimasukkan ke dalam model. Setiap tambahan satu variabel independen, maka nilai $\left(R^{2}\right)$ pasti meningkat tidak peduli apakah variabel tersebut berpengaruh secara signifikan terhadap variabel dependen. Oleh karena itu banyak peneliti menganjurkan untuk menggunakan nilai adjusted $R^{2}$ pada saat mengevaluasi mana model regresi terbaik. Tidak seperti $R^{2}$, nilai adjusted $R^{2}$ dapat naik atau turun apabila satu variabel independen ditambahkan ke dalam model

\begin{tabular}{|c|c|c|c|c|c|}
\hline Variabel & $\begin{array}{c}\text { no. } \\
\text { Aitem }\end{array}$ & $\begin{array}{c}\text { Corrected } \\
\text { Item-Total } \\
\text { Correlation } \\
\mathbf{N}=\mathbf{3 0}\end{array}$ & \begin{tabular}{|c|} 
Corrected \\
Item-Total \\
Correlation \\
$\mathrm{N}=100$ \\
\end{tabular} & $\begin{array}{c}\mathbf{R} \\
\text { table }\end{array}$ & Ket \\
\hline \multirow{4}{*}{$\begin{array}{l}\text { Kepercayaan / } \\
\text { Trustworthiness }\end{array}$} & 1 & 0.707 & 0.811 & 0.300 & Valid \\
\hline & 2 & 0.811 & 0.787 & 0.300 & Valid \\
\hline & 3 & 0.774 & 0.669 & 0.300 & Valid \\
\hline & 4 & 0.811 & 0.758 & 0.300 & Valid \\
\hline \multirow{5}{*}{$\begin{array}{l}\text { Keahlian / } \\
\text { Expertise }\end{array}$} & 1 & 0.723 & 0.828 & 0.300 & Valid \\
\hline & 2 & 0.845 & 0.860 & 0.300 & Valid \\
\hline & 3 & 0.821 & 0.867 & 0.300 & Valid \\
\hline & 4 & 0.809 & 0.878 & 0.300 & Valid \\
\hline & 5 & 0.823 & 0.889 & 0.300 & Valid \\
\hline \multirow{5}{*}{$\begin{array}{c}\text { Daya Tarik / } \\
\text { Attractiveness }\end{array}$} & 1 & 0.796 & 0.860 & 0.300 & Valid \\
\hline & 2 & 0.857 & 0.890 & 0.300 & Valid \\
\hline & 3 & 0.827 & 0.909 & 0.300 & Valid \\
\hline & 4 & 0.786 & 0.905 & 0.300 & Valid \\
\hline & 5 & 0.637 & 0.804 & 0.300 & Valid \\
\hline \multirow{5}{*}{ Minat Beli } & 1 & 0.732 & 0.751 & 0.300 & Valid \\
\hline & 2 & 0.487 & 0.445 & 0.300 & Valid \\
\hline & 3 & 0.826 & 0.810 & 0.300 & Valid \\
\hline & 4 & 0.811 & 0.861 & 0.300 & Valid \\
\hline & 5 & 0.859 & 0.885 & 0.300 & Valid \\
\hline
\end{tabular}
(Ghozali, 2011 dalam Kumalasari 2018).

\section{HASIL PENELITIAN DAN PEMBAHASAN}

\section{Uji Instrumen}

\section{Uji Validitas}

Tabel 4.1

Sumber: Data Diolah SPSS (2019)

Berdasarkan tabel 4.1 di atas menunjukkan bahwa besarnya nilai r-hitung seluruh pertanyaan nilainya lebih besar dari r-tabel 0,300. Dengan demikian dapat disimpulkan bahwa seluruh instrumen pertanyaan dinyatakan valid dan kuisioner dalam penelitian ini dapat digunakan untuk analisis selanjutnya, yaitu regresi linier berganda. 


\section{Uji Reliabilitas}

Tabel 4.2

\begin{tabular}{|l|c|c|c|l|}
\hline Variabel & $\begin{array}{l}\text { Cronbach's } \\
\text { Alpha } \\
\mathrm{N}=30\end{array}$ & $\begin{array}{l}\text { Cronbach's } \\
\text { Alpha } \\
\mathrm{N}=100\end{array}$ & $\begin{array}{l}\text { Batas } \\
\text { kritis }\end{array}$ & Ket. \\
\hline Kepercayaan & 0.830 & 0.875 & $>0.6$ & Reliable \\
\hline Keahlian & 0.828 & 0.951 & $>0.6$ & Reliable \\
\hline Daya Tarik & 0.829 & 0.954 & $>0.6$ & Reliable \\
\hline Minat Beli & 0.815 & 0.897 & $>0.6$ & Reliable \\
\hline
\end{tabular}

Sumber: Data Diolah SPSS (2019)

Berdasarkan hasil uji reliabilitas seperti yang terangkum dalam tabel di atas, dapat diketahui bahwa nilai koefisien Cronbach Alpha seluruh varaibel penelitian lebih besar dari 0,6. Dengan mengacu pada pendapat yang dikemukakan oleh Ghozali (2005), maka semua butir pertanyaan dalam variabel penelitian tersebut reliabel dan dapat digunakan untuk penelitian selanjutnya.

\section{Karakteristik Responden}

\section{Berdasarkan Jenis Kelamin}

Tabel 4.3

\begin{tabular}{|c|c|c|}
\hline Kategori & Frekuensi & Prosentase \% \\
\hline Laki-Laki & 23 & 23.0 \\
\hline Perempuan & 77 & 77.0 \\
\hline Total & 100 & 100.0 \\
\hline
\end{tabular}

Sumber: Data Diolah SPSS (2019)

Berdasarkan tabel 4.3 dapat diketahui bahwa karakteristik responden berdasarkan Jenis Kelamin Pembeli Teh Kotak, sebagian besar adalah perempuan yaitu sebanyak 77 responden (77\%), karena celebrity endorsernya adalah lakilaki yang tampan dan bertalenta sehingga menarik bagi perempuan, dan juga rasa buah-buahan yang segar sangat digemari oleh perempuan, tapi bukan berarti lakilaki tidak menyukainya, hanya saja lebih dominan perempuan dilihat dari celebrity endorser dan karakteristik rasa teh kotak.

\section{Berdasarkan Usia}

Tabel 4.4

\begin{tabular}{|l|c|c|}
\hline \multicolumn{1}{|c|}{ Kategori } & Frekuensi & Prosentase \\
\hline$<20$ Tahun & 15 & 15.0 \\
\hline $21-25$ Tahun & 83 & 83.0 \\
\hline$>30$ Tahun & 2 & 2.0 \\
\hline Total & 100 & 100.0 \\
\hline
\end{tabular}

Sumber: Data Diolah SPSS (2019)

Berdasarkan tabel 4.4 dapat diketahui bahwa karakteristik responden berdasarkan umur pembeli teh kotak, sebagian besar adalah responden berumur 21-25 tahun yaitu sebanyak 83 responden (83\%). Peneliti mengambil sampel masyarakat umur produktif di Kabupaten Bantul, jadi kebanyakan respondennya yang beruur 21-25 tahun. karakteristik anak muda sendiri yang mudah tertarik dan dipengaruhi dengan hal baru dan rasa baru sehingga sering dijadikan sasaran promosi penjualan.

\section{Berdasarkan Pendidikan Terakhir} Tabel 4.5

\begin{tabular}{|l|c|c|}
\hline \multicolumn{1}{|c|}{ Kategori } & Frekuensi & Prosentase \\
\hline SMP & 1 & 1.0 \\
\hline SMA & 46 & 46.0 \\
\hline D3 & 6 & 6.0 \\
\hline S1 & 43 & 43.0 \\
\hline Lainnya & 4 & 4.0 \\
\hline Total & 100 & 100.0 \\
\hline
\end{tabular}

Sumber: Data Diolah SPSS (2019)

Berdasarkan tabel 4.5 dapat diketahui bahwa karakteristik responden berdasarkan pendidikan, sebagian besar adalah responden pendidikan terakhirnya SMA yaitu sebanyak 46 responden (46\%). Karena peneliti menyasar responden umur produktif jadi kebanyakan respondennya adalah mahasiswa yang berumur diatas 17 tahun, mahasiswa biasanya sedang aktif-aktifnya dan produktif di berbagai bidang. 
4. Berdasarkan Pendapatan Per Bulan

Tabel 4.6

\begin{tabular}{|l|c|c|}
\hline \multicolumn{1}{|c|}{ Kategori } & Frekuensi & Prosentase \\
\hline$<1.5 \mathrm{Jt}$ & 63 & 63.0 \\
\hline $1.5 \mathrm{jt}-2 \mathrm{jt}$ & 20 & 20.0 \\
\hline $2.1 \mathrm{jt}-2.5 \mathrm{jt}$ & 5 & 5.0 \\
\hline$>2.5 \mathrm{jt}$ & 12 & 12.0 \\
\hline Total & 100 & 100.0 \\
\hline
\end{tabular}

Sumber: Data Diolah SPSS (2019)

Berdasarkan tabel 4.6 dapat diketahui bahwa karakteristik responden berdasarkan pendapatan, sebagian besar adalah responden memiliki pendapatan $<$ $1,5 \mathrm{juta} / \mathrm{bulan}$ yaitu sebanyak 63 responden (63\%). Responden dengan pendapatan kurang dari 1,5 juta/bulan karena mereka sebagian besar masih dibiayai orang tua jadi pendapatan utama mereka dari uang saku orang tua.

\section{Berdasarkan Sumber Informasi Celebrity Endorse}

Tabel 4.7

\begin{tabular}{|l|c|c|}
\hline \multicolumn{1}{|c|}{ Kategori } & Frekuensi & Prosentase \\
\hline TV & 51 & 51.0 \\
\hline Media Sosial & 46 & 46.0 \\
\hline Teman & 2 & 2.0 \\
\hline Lainnya & 1 & 1.0 \\
\hline Total & 100 & 100.0 \\
\hline
\end{tabular}

Sumber: Data Diolah SPSS (2019)

Berdasarkan tabel 4.7 dapat diketahui bahwa karakteristik responden berdasarkan sumber dari mana mereka mengetahui the kotak, sebagian besar adalah responden mengetahui teh kotak rasa buah dari televisi (TV) yaitu sebanyak 51 responden (51\%). TV merupakan salah satu alat komunikasi pemasaran satu arah, hampir semua orang setiap harinya melihat TV, baik melihat berita, sinetron, talk show hampir semua orang melihat televisi setiap harinya sehingga banyak sekali informasi yang bisa didapatkan dari TV, salah satunya produk baru teh kotak rasa buah. Selain TV responden juga banyak mengetahui teh kotak melalui media sosial, karena hampir setiap orang menggunakan media sosial, entah itu facebook, instagram, dan lain sebaginya, dan di dalam media sosial tersebut sering digunakan sebagian salah satu media pemasaran oleh beberapa perusahaan.

\section{Sumber Informasi Produk Teh Kotak} Tabel 4.8

\begin{tabular}{|l|c|c|}
\hline \multicolumn{1}{|c|}{ Kategori } & Frekuensi & Prosentase \\
\hline TV & 46 & 46.0 \\
\hline Media sosial & 5 & 5.0 \\
\hline Toko/ Swalayan & 47 & 47.0 \\
\hline Lainnya & 2 & 2.0 \\
\hline Total & 100 & 100.0 \\
\hline
\end{tabular}

Sumber: Data Diolah SPSS (2019)

Berdasarkan tabel 4.8 dapat diketahui bahwa karakteristik responden berdasarkan sumber dari mana dia mengetahui teh kotak rasa buah, sebagian besar adalah responden tahu produk teh kotak rasa buah dari toko atau swalayan, yaitu sebanyak 47 responden (47\%) dan dari TV sebanyak 46 responden (46\%). Display teh kotak yang terpampang di toko atau swalayan membuat konsumen mengetahui produk teh kotak.

\section{Berdasarkan Intensitas Pembelian} Produk Teh Kotak Dalam 1 Bulan

Tabel 4.9

\begin{tabular}{|c|c|c|}
\hline Kategori & Frekuensi & Prosentase \\
\hline $1-3 \mathrm{kali}$ & 77 & 77.0 \\
\hline $4-6 \mathrm{kali}$ & 11 & 11.0 \\
\hline $7-10 \mathrm{kali}$ & 7 & 7.0 \\
\hline$>10 \mathrm{kali}$ & 5 & 5.0 \\
\hline Total & 100 & 100.0 \\
\hline
\end{tabular}

Sumber: Data Diolah SPSS (2019)

Berdasarkan tabel 4.9 dapat diketahui bahwa karakteristik responden berdasarkan intensitas pembelian Teh Kotak, sebagian besar responden membeli the kotak dengan intensitas 1-3 kali dalam 1 bulan yaitu sebanyak 77 
responden (77\%). Karena teh kotak rasa buah merupakan inovasi produk baru dari teh kotak sehingga banyak yang baru mencoba teh kotak rasa buah ini karena iklan di TV, jadi intensitas pembeliannya belum terlalu banyak.

\section{Uji Asumsi Klasik}

\section{Uji Normalitas}

Tabel 4.10

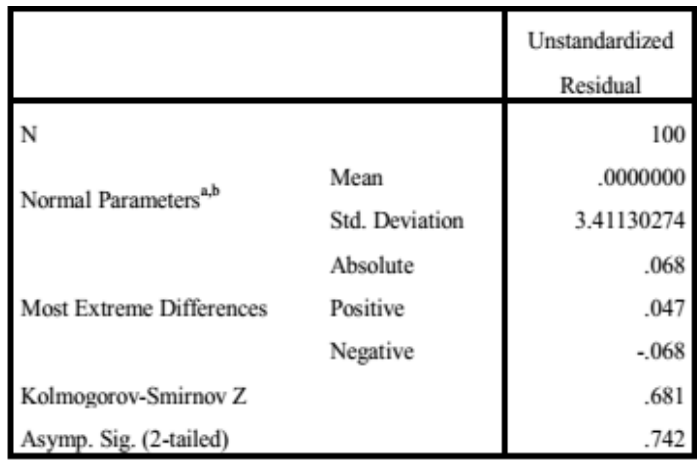

Sumber: Data Diolah SPSS (2019)

Data normal karena nilai signifikansi $0.742(0.742>0.05)$

Normal P.P Plot of Regression Standardized Residual

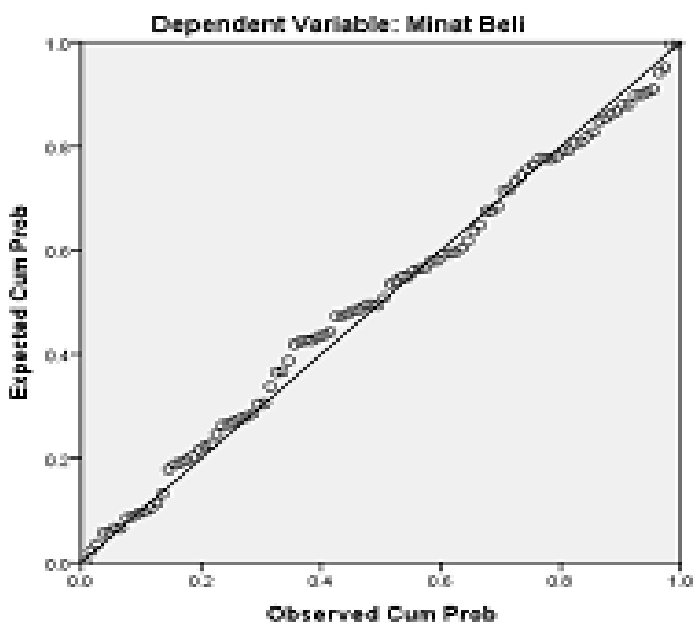

Sumber: Data Diolah SPSS (2019)

\section{Gambar 4.1. Uji Normalitas}

Data diatas menunjukkan bahwa garis yang menggambarkan data mengikuti arah garis diagonal, jadi kesimpulannya data normal karena titik-titik berada di atas dan di bawah sumbu diagonal.

\section{Uji Multikolinieritas}

Tabel 4.11

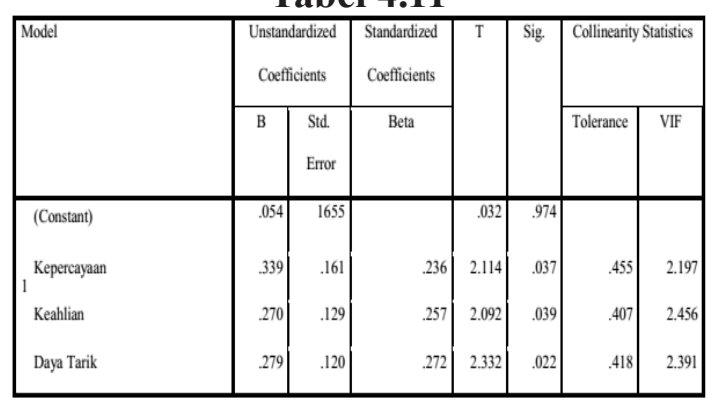

Sumber: Data Diolah SPSS (2019)

Tabel 4.12

\begin{tabular}{|l|r|r|l|}
\hline \multicolumn{1}{|c|}{ Variabel } & Tolerance & \multicolumn{1}{c|}{ VIF } & Keterangan \\
\hline Kepercayaan & 0.455 & 2.197 & Tidak terjadi multikolinieritas \\
\hline Keahlian & 0.407 & 2.456 & Tidak terjadi multikolinieritas \\
\hline Daya tarik & 0.418 & 2.391 & Tidak terjadi multikolinieritas \\
\hline
\end{tabular}

Sumber: Data Diolah SPSS (2019)

Berdasarkan tabel 4.12 dapat diketahui bahwa nilai tolerance value $>$ 0,10 atau nilai VIF $<10$ maka tidak terjadi multikolinieritas.

\section{Uji Heteroskedastisitas}

Tabel 4.13

\begin{tabular}{|c|c|c|c|c|c|c|}
\hline \multirow[t]{2}{*}{ Mod } & & \multicolumn{2}{|c|}{ Unstandardized Coefficients } & \multirow{2}{*}{$\begin{array}{c}\begin{array}{c}\text { Standardized } \\
\text { Coefficients }\end{array} \\
\text { Beta }\end{array}$} & \multirow[t]{2}{*}{$\mathrm{T}$} & \multirow[t]{2}{*}{ Sig. } \\
\hline & & B & Std. Error & & & \\
\hline \multirow{4}{*}{1} & (Constant) & 2.877 & 1.066 & & 2.698 & .008 \\
\hline & Kepercayaan & .054 & .103 & .078 & .519 & .605 \\
\hline & Keahlian & .012 & .083 & .022 & .139 & .890 \\
\hline & Daya tarik & .044 & .077| & .089 & .567 & .572 \\
\hline
\end{tabular}

Sumber: Data Diolah SPSS (2019)

Tabel 4.14

\begin{tabular}{|l|r|r|c|}
\hline \multicolumn{1}{|c|}{ Variabel } & \multicolumn{1}{c|}{ Sig } & Batas & Keterangan \\
\hline Kepercayaan & 0.605 & $>0,05$ & Tidak terjadi heterokedasitas \\
\hline Keahlian & 0.890 & $>0,05$ & Tidak terjadi heterokedasitas \\
\hline Daya tarik & 0.572 & $>0,05$ & Tidak terjadi heterokedasitas \\
\hline
\end{tabular}

Sumber: Data Diolah SPSS (2019)

Berdasarkan tabel 4.14 dapat diketahui bahwa nilai probabilitas lebih besar dari 0,05, dengan demikian variabel yang diajukan dalam penelitian tidak terjadi heterokedasitas. 
Analisis Regresi Linier Berganda

Tabel 4.15

\begin{tabular}{|l|c|c|c|c|c|c|c|}
\hline \multicolumn{1}{|c|}{ Variabel } & B & Beta & $\begin{array}{c}\mathrm{t} \\
\text { hitung }\end{array}$ & Sig t & $\mathbf{r}$ & $\mathrm{r}^{2}$ & Ket \\
\hline (Constant) & .054 & & & & & & \\
\hline Kepercayaan & 0.339 & 0.236 & 2.114 & 0.037 & 0.591 & 0.349 & Sig \\
\hline Keahlian & 0.270 & 0.247 & 2.092 & 0.039 & 0.605 & 0.366 & Sig \\
\hline Daya tarik & 0.279 & 0.272 & 2.332 & 0.022 & 0.610 & 0.372 & Sig \\
\hline Sig F & 0.000 & & & & & & \\
\hline $\begin{array}{c}\text { Adjusted R } \\
\text { square }\end{array}$ & 0.438 & & & & & & \\
\hline $\mathbf{R}$ & 0,674 & & & & & & \\
\hline $\mathbf{R}^{2}$ & 0,455 & & & & & & \\
\hline $\begin{array}{c}\text { Variabel } \\
\text { Dependent }\end{array}$ & $\begin{array}{c}\text { Minat } \\
\text { Beli }\end{array}$ & & & & & & \\
\hline
\end{tabular}

Sumber: Data Diolah SPSS (2019)

Berdasarkan tabel 4.15 di atas perhitungan regresi linear berganda dengan menggunakan program SPSS didapat hasil sebagai berikut: $Y=0.054+0.339 X_{1}+0.270 X_{2}+0.279 X_{3}$

1. Konstanta $=0.054$. Artinya jika tidak ada variabel Kepercayaan, Keahlian dan Daya tarik yang mempengaruhi Minat Beli, maka kepuasan sebesar 0.054 satuan.

2. $\quad \mathrm{b} 1=0$.339. Artinya jika Kepercayaan meningkat sebesar satu satuan maka minat beli akan meningkat sebesar 0.339 dengan anggapan variabel bebas lain tetap.

3. $b 2=0.270$. Artinya jika Variabel Keahlian meningkat sebesar satu satuan maka Minat Beli akan meningkat sebesar 0.270 dengan anggapan variable bebas lain tetap.

4. $\quad \mathrm{b} 3=0.279$. Artinya jika Variabel Daya Tarik meningkat sebesar satu satuan maka Kinerja sebesar 0.279 dengan anggapan variabel bebas lain tetap.

\section{Uji Hipotesis}

1. Uji Parsial (Uji T)

Tabel 4.16. Hasil Uji T

\begin{tabular}{|c|c|c|c|c|c|}
\hline \multirow[t]{2}{*}{ Model } & \multicolumn{2}{|c|}{$\begin{array}{c}\text { Unstandardized } \\
\text { Coefficients }\end{array}$} & $\begin{array}{l}\text { Standardized } \\
\text { Coefficients }\end{array}$ & $\mathrm{t}$ & Sig. \\
\hline & B & Std. Error & Beta & & \\
\hline (Constant) & .054 & 1.655 & & .032 & .974 \\
\hline${ }_{1}$ Kepercayaan & .339 & .161 & .236 & 2.114 & .037 \\
\hline Keahlian & .270 & .129 & .247 & 2.092 & .039 \\
\hline Daya tarik & .279 & .120 & .272 & 2.332 & .022 \\
\hline
\end{tabular}

Sumber: Data Diolah SPSS (2019)
Hasil pengujian analisis regresi linear berganda menunjukkan bahwa terdapat nilai signifikansi sebesar 0.037 (0.037 > $0,05)$. Nilai tersebut dapat membuktikan hiopotesis kerja diterima, yang berarti bahwa ada pengaruh kepercayaan terhadap minat beli.

Hasil pengujian analisis regresi linear berganda menunjukkan bahwa terdapat nilai signifikansi sebesar 0.039 (0.039> 0,05). Nilai tersebut dapat membuktikan hiopotesis kerja diterima, yang berarti bahwa ada pengaruh keahlian terhadap minat beli.

Hasil pengujian analisis regresi linear berganda menunjukkan bahwa terdapat nilai signifikansi sebesar $0.022(0.022>$ $0,05)$. Nilai tersebut dapat membuktikan hipotesis kerja diterima, yang berarti bahwa ada pengaruh daya tarik terhadap minat beli.

\section{Uji Koefisien Determinasi}

Tabel 4.17. Hasil Uji R Square

\begin{tabular}{|l|c|c|c|c|c|c|c|}
\hline \multicolumn{1}{|c|}{ Variabel } & B & Beta & $\begin{array}{c}\mathbf{t} \\
\text { hitung }\end{array}$ & Sigt & $\mathbf{r}$ & $\mathbf{r}^{2}$ & Ket \\
\hline (Constant) & .054 & & & & & & \\
\hline Kepercayaan & 0.339 & 0.236 & 2.114 & 0.037 & 0.591 & 0.349 & Sig \\
\hline Keahlian & 0.270 & 0.247 & 2.092 & 0.039 & 0.605 & 0.366 & Sig \\
\hline Daya tarik & 0.279 & 0.272 & 2.332 & 0.022 & 0.610 & 0.372 & Sig \\
\hline Sig F & 0.000 & & & & & & \\
\hline $\begin{array}{c}\text { Adjusted R } \\
\text { square }\end{array}$ & 0.438 & & & & & & \\
\hline $\mathbf{R}$ & 0,674 & & & & & & \\
\hline $\mathbf{R}^{2}$ & 0,455 & & & & & & \\
\hline $\begin{array}{c}\text { Variabel } \\
\text { Dependent }\end{array}$ & $\begin{array}{c}\text { Minat } \\
\text { Beli }\end{array}$ & & & & & & \\
\hline
\end{tabular}

Sumber: Data Diolah SPSS (2019)

Berdasarkan analisis regresi linear berganda menunjukkan besarnya koefisien determinasi $(\mathrm{R}$ square $)=0,455$, artinya variabel bebas secara bersama-sama mempengaruhi variabel terikat sebesar $45 \%$ sisanya sebesar $55 \%$ dipengaruhi oleh variabel lain yang tidak dimasukkan dalam model penelitian. 


\section{Pembahasan}

\section{Pengaruh Positif Trustworthness terhadap Minat Beli}

Hasil pengujian hipotesis secara parsial (Uji T) terhadap trustworthness menunjukkan nilai koefisien sebesar 0,339 dan nilai probabilitas sebesar 0,037 , yang artinya trustworthness berpengaruh positif, sehingga hipotesis pertama yang mengatakan trustworthness berpengaruh positif terhadap minat beli produk teh kotak rasa buah diterima. Hasil tersebut mendukung penelitian terdahulu yang dilakukan oleh Lolasary (2015) dan Hafisa (2018) yang menunjukkan hasil bahwa trustworthness berpengaruh positif terhadap minat beli.

Efektif atau tidaknya suatu iklan tergantung juga pada kepercayaan konsumen terhadap celebrity endorser, sebab ketika konsumen mempercayai seorang selebriti, maka ketika adanya iklan yang dibintangi oleh selebriti tersebut konsumen bisa tertarik dengan produk itu atau bisa menimbulkan minat beli. Dalam penelitian Sertoglu banyak literatur mendukung efek positif dari kepercayaan pada efektivitas (Sertoglu, 2014).

Paradigma kepercayaan dalam komunikasi meliputi tingkat kepercayaan pendengar, tingkat penerimaan, pembicara, dan pesan. Komunikator dapat dipercaya adalah persuasif, apakah seorang ahli atau tidak. Kepercayaan dapat didefinisikan sebagai kejujuran, integritas, dan kepercayaan yang dimiliki oleh endorser. Ini adalah tingkat kepercayaan konsumen dalam niat komunikator untuk menyampaikan pernyataan yang dianggapnya paling valid.

\section{Pengaruh Positif Expertise terhadap Minat Beli}

Hasil pengujian hipotesis secara parsial (Uji $\mathrm{T}$ ) terhadap expertise menunjukkan nilai koefisien sebesar 0,270 dan nilai probabilitas sebesar 0,039 , yang artinya expertise berpengaruh positif, sehingga hipotesis kedua yang mengatakan expertise berpengaruh positif terhadap minat beli produk teh kotak rasa buah diterima. Hasil tersebut mendukung penelitian terdahulu yang dilakukan oleh Lolasary (2015) dan Hafisa (2018) yang menunjukkan hasil bahwa expertise berpengaruh positif terhadap minat beli.

Expertise juga disebut sebagai otoritativeness, kompetensi, expertness, atau kualifikasi. Keahlian adalah sejauh mana endorser dianggap memiliki pengetahuan, pengalaman atau keterampilan yang memadai untuk mempromosikan produk. Keahlian dari endorser tidak penting kecuali konsumen menganggapnya demikian. Keahlian diterima sebagai komponen yang paling penting untuk disetujui agar berhasil. Selebriti mungkin dianggap memiliki keahlian lebih dari juru bicara yang dibuat. Keahlian celebrity endorser adalah sejauh mana komunikator dianggap sebagai sumber pernyataan yang sah (Sertoglu, 2014).

\section{Pengaruh Positif Attractive terhadap Minat Beli}

Hasil pengujian hipotesis secara parsial (Uji T) terhadap attractive menunjukkan nilai koefisien sebesar 0,279 dan nilai probabilitas sebesar 0,022, yang artinya attractive berpengaruh positif, sehingga hipotesis ketiga yang mengatakan attractive berpengaruh positif terhadap minat beli produk teh kotak rasa buah diterima. Hasil tersebut mendukung penelitian terdahulu yang dilakukan oleh Prabowo (2014) dan Sertoglu (2014) yang menunjukkan hasil bahwa attractive berpengaruh positif terhadap minat beli.

Attractiveness atau daya tarik dapat menjadi faktor penting dalam menciptakan pesan yang efektif. Menarik endorser memiliki lebih banyak pengaruh atas konsumen dibandingkan dengan yang kurang menarik. Dalam penelitian Sertoglu daya tarik secara positif mempengaruhi evaluasi, itu tidak material dalam mempengaruhi niat pembelian. Meskipun pengiklan sering memilih 
pendukung berdasarkan daya tarik fisik mereka untuk mempengaruhi sikap konsumen, dalam penelitian ini juga menyatakan bahwa sumber daya tarik mungkin hanya efektif jika produk meningkatkan daya tarik pengguna sebagaimana juga dinyatakan dalam model pencocokan (Sertoglu, 2014).

Attractiveness adalah komponen penting dari kredibilitas, daya tarik adalah stereotip dari asosiasi positif kepada seseorang dan tidak hanya memiliki daya tarik fisik tetapi juga karakteristik lain seperti kepribadian dan kemampuan atletik. Bukti eksperimental mengenai dampak komunikator yang menarik secara fisik pada berbagai tindakan tergantung, dan menyatakan bahwa komunikator yang menarik lebih disukai, disukai, dan diyakini memiliki dampak positif pada produk daripada yang tidak menarik. Endorser yang dianggap menarik lebih cenderung mengarahkan niat pembelian.

\section{KESIMPULAN DAN SARAN}

\section{Kesimpulan}

Berdasarkan hasil penelitian di atas, maka dapat disimpulkan bahwa:

1. Hasil pengujian hipotesis secara parsial (Uji T) terhadap trustworthness menunjukkan nilai koefisien sebesar 0,339 dan nilai probabilitas sebesar 0,037 , yang artinya trustworthness berpengaruh positif, sehingga hipotesis pertama yang mengatakan trustworthness berpengaruh positif terhadap minat beli produk teh kotak rasa buah diterima.

2. Hasil pengujian hipotesis secara parsial (Uji T) terhadap expertise menunjukkan nilai koefisien sebesar 0,270 dan nilai probabilitas sebesar 0,039 , yang artinya expertise berpengaruh positif, sehingga hipotesis kedua yang mengatakan expertise berpengaruh positif terhadap minat beli produk teh kotak rasa buah diterima.

3. Hasil pengujian hipotesis secara parsial (Uji T) terhadap attractive menunjukkan nilai koefisien sebesar 0,279 dan nilai probabilitas sebesar 0,022 , yang artinya attractive berpengaruh positif, sehingga hipotesis ketiga yang mengatakan attractive berpengaruh positif terhadap minat beli produk teh kotak rasa buah diterima.

\section{Saran}

Saran yang dapat diberikan dalam penelitian ini diantaranya:

1. Sebaiknya di beberapa kesempatan Rizky Febian membawa dan meminum teh kotak yang dia iklankan agar masyarakat semakin yakin lagi dengan produk yang dia iklankan.

2. Mengajak Rizky Febian di beberapa event teh kotak.

3. Promosi yang meyakinkan konsumen dan relasi yang dibutuhkan sangat sesuai oleh konsumen.

4. Sponsor pada acara anak muda, konser musik dan lain sebagainya, membuat keputusan pembelian konsumen menjadi lebih mudah. Konsumen akan membeli produk yang konsumen inginkan dan percayai berdasarkan pengalaman selama mereka membeli produk teh kotak. Kepercayaan akan terbangun karena adanya harapan bahwa pihak lain akan memberikan sesuai dengan kebutuhan dan keinginan konsumen.

5. Mengganti selebriti yang lebih berpengalaman dan pengetahuannya luas dalam dunia endorse.

6. Memilih celebrity endorse yang keahliannya sesuai dengan produk, misalnya seorang vlogger makan terkenal, atau seorang juru masak yang handal.

7. Dilihat dari hasil analisis persepsi konsumen yang harus ditingkatkan lagi, yaitu pada indikator elegant, perusahaan mengganti celebrity endorse yang lebih elegant.

8. Untuk usia anak muda celebrity endorse yang dipilih seharusnya yang berpakaian casual, santai tapi tetap rapi. 


\section{DAFTAR PUSTAKA}

Ardiansyah, Lutfi, dkk. (2015). Pengaruh Daya Tarik Iklan terhadap Efektivitas Iklan. Fakultas Ilmu Administrasi Universitas Brawijaya Malang.

Cholifah, Nike, dkk. (2016). Pengaruh Celebrity Endorser terhadap Brand Image. Fakultas Ilmu Administrasi Universitas Brawijaya Malang.

Dama, Daniel. (2016). Analisis Faktor-Faktor yang Mempengaruhi Minat Beli Konsumen dalam Memilih Laptop Acer di Toko Lestari Komputer Manado. Fakultas Ekonomi dan Bisnis Universitas Sam Ratulangi Manado.

Darmadi, Didik. (2013). Pengaruh Promosi Penjualan terhadap Penjualan (Studi Kasus PT Astra Internasional Tbk-TSO Cabang Soetoyo Malang). Fakultas Ilmu Administrasi Universitas Brawijaya Malang.

Ghozali, Imam. (2005). Aplikasi Analisis Multivariate dengan Program SPSS. Semarang. Penerbit Universitas Diponegoro.

Hafisa, Dinda Yulia. (2018). Pengaruh Celebrity Endorser terhadap Minat Beli Produk Kosmetik Halal "Wardah". Fakultas Ekonomi Universitas Islam Indonesia Yogyakarta.

Imasari, Kartika. (2010). Pengaruh Media Periklanan terhadap Pengambilan Keputusan Siswa SMU untuk Mendaftar di Universitas Kristen Maranatha: Sikap Konsumen sebagai Variabel Moderasi. Universitas Kristen Maranatha Bandung.
Kotler, Philip dan Amstrong, Gery. (2004). Dasar-dasar Pemasaran jilid 2. Jakarta: PT Index.

Kotler, Philip dan Keller, Kevin Lane. (2007). Manajemen Pemasaran Edisi 12. Jakarta: PT Index.

Kumalasari, Nur. (2018). Analisis Pengaruh Citra Merek, Kualitas Produk, dan Kualitas Pelayanan terhadap Kepuasan dan Loyalitas Konsumen Tempe 5.17 Salatiga. Fakultas Ekonomi Universitas Islam Indonesia Yogyakarta.

Lamb, Charles W. dkk. (2001). Pemasaran. Jakarta: PT Salemba Emban Patria.

Lolasary. Femia. (2015). Pengaruh Celebrity EndorserterhadapMinatBeliKonsumen pada Produk Fashion yang Diiklankan melalui Twitter. Fakultas Ilmu Sosial dan Ilmu Politik, Jurusan Administrasi Bisnis Universitas Pembangunan Nasional "Veteran" Yogyakarta.

Rodriguez, Karina P. (2008). Apparel Brand Endorsers and Their Effects on Purchase Intentions: A Study of Philippine Consumers. Philippine.

Sertoglu, Aysegul Ermec. (2014). Examining the Effect of Endorser Credibility on the Consumers' Buying Intentions: An Empirical Study in Turkey. Department of International Trade, Gazi University, Ankara Turkey.

Sintani, Laurencia. (2016). Pengaruh Penggunaan Celebrity Endorser Isyana Sarasvati dalam Iklan "Isyana vs Gangster" terhadap Brand Awareness Masyarakat Surabaya. Universitas Kristen Petra Surabaya.

Sugiyono. (2005). Memahami Penelitian Kualitatif. Bandung: Alfabeta. 